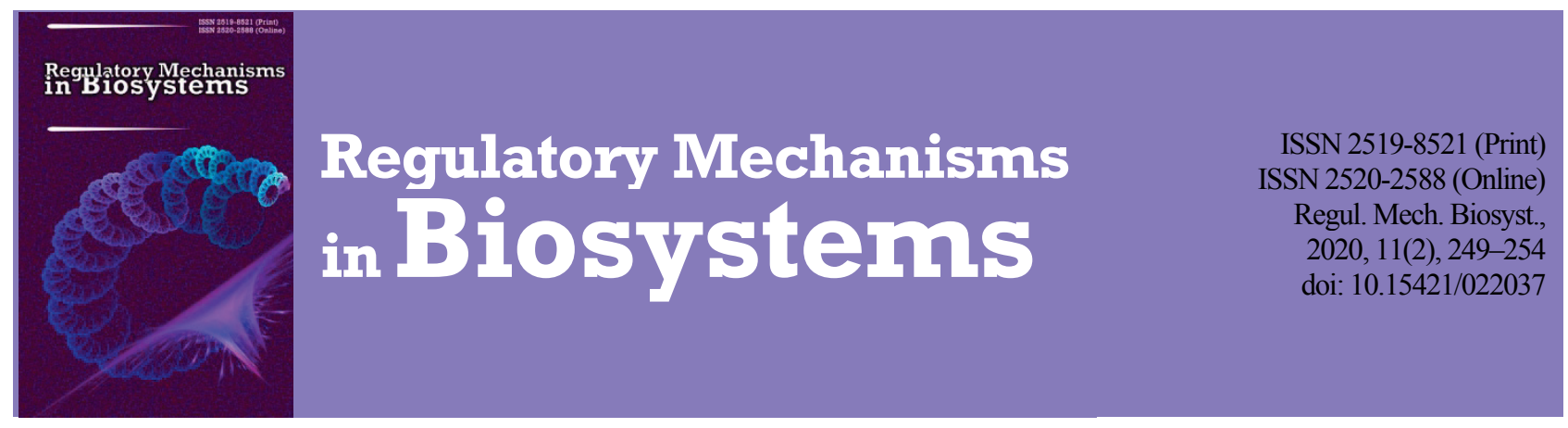

\title{
Association of BoLA-DRB3.2 alleles with fusobacteriosis in cows
}

\author{
T. M. Suprovych*, M. P. Suprovych*, R. V. Kolinchuk*, T. M. Karchevska*, I. O. Chornyi*, V. A. Kolodiy** \\ *State Agrarian and Engineering University in Podilya, Kamianets-Podilskyi, Ukraine \\ **Kamianets-Podilskyi National Ivan Ohienko University, Kamianets-Podilskyi, Ukraine
}

Article info

Received 14.04.2020

Received in revised form 20.05.2020

Accepted 21.05.2020

State Agrarian and

Engineering University

in Podilya, Shevchenko st

13, Kamianets-Podilskyi,

32300, Ukraine.

Tel.: +38-098-576-30-18

E-mail:

suprovycht@gmail.com

Kamianets-Podilskyi

National Ivan Ohienko

University, Ohienko st., 61 ,

Kamianets-Podilskyi,

32300, Ukraine.

Tel.: +38-067-687-06-71

E-mail:kolodiyva@ukr.net

\section{Introduction}

Fusobacteriosis (necrobacteriosis) is a disease which tends to spread in the most countries of the world with developed animal husbandry. This infectious disease is characterized by purulent-necrotic lesions mostly on the lower parts of the limbs, in some cases - in the oral cavity, in the udder, reproductive organs, liver, lungs, muscles and other tissues and organs (Vinnikov et al., 2019). The disease's pathogen, Fusobacterium necrophorum, is a constant inhabitant of the gastrointestinal tract of both domestic and wild animals, common in the environment (animal housing, grazing areas, manure, soil, pastures, water from reservoirs without an outlet, etc.). The purpose of breeding dairy cattle is concentrated not only on the production characteristics, but also characteristics of health and life span, which nectobacteriosis directly affects. It causes death of up to $30 \%$ of adult cattle and $80 \%$ of young animals.

The main problem of nectobacteriosis in modern dairy herds is sthe pread of lameness. It accounts for $40-60 \%$ of all diseases of the limbs of cattle (Skorodumov, 2007). Lesions of the limbs and hoofs are some of the main factors which drive dairy cows out of the working herd, comprising $10-15 \%$ of the unintended culling (Cha et al., 2010). Today, laminitis is the third cause, after mastitis and infertility (Hedges et al., 2001), of significant economic losses in dairy livestock farming (Ózsvári, 2017). According to (Ettema \& Østergaard, 2006), the losses from one case of lameness are estimated $€ 178-278$. Losses from footrot are estimated in the range of $\$ 120-216$, resulting in loss of $40 \%$ due to decrease in the milk production, $26 \%$ due to decrease of fertility and $34 \%$ for treatment (Cha et al., 2010). Recently, cattle more and more often have suffered loose housing of animals caused specific problems, which farmers have not faced during stanchion-tied housing. Almost all domestic farms currently face the problem of nectobacteriosis. Spread of this disease most often occurs in large farms housing highly productive animals. The causes of nectobacteriosis are multi-factorial: violations of the technology of housing and the norms of feeding of animals, uncontrolled import of cattle from abroad and mass holsteinization of the domestic breeds (Sokolovsky \& Birukova, 2016; Suprovych et al., 2017).

Nectobacteriosis most often manifests as associated infection against the background of reduced resistance of the organism, immune deficiency of B-cellular link of the immunity, negative impact of exo- and endogenous stress factors on animals (Zhovnir et al., 2015). Therefore, there obviously is a necessity of the development of practical measures for the evaluation of genetic susceptibility (or by contrast resistibility) of the animals to nectobacteriosis.

Methods of molecular genetics combined with common tools of animal breeding are important for balancing the selection and optimization of the programs of breeding of animals. In scientific studies, the data on genetic aspects of nectobacteriosis are quite limited. Genetic selection for the reduction of hoof lesion is developing slowly, because the violations are not being recorded (Van der Spek et al., 2015). Systematic genetic evaluation of the health of hooves based on planned cleaning is being performed in some countries (Netherlands, Finland, Sweden, Canada) only since 2010 (Heringstad et al., 2018). Inheritance of the most often analyzed lesions of the hoof was usually low, ranging in the linear assessments $0.01-$ 0.14 and threshold values $0.06-0.39$. The assessed genetic correlations 
between the hoof lesions ranged 0.40-0.98 (Heringstad et al., 2018). According to Boettcher et al. (1998), the assessment of inheritance of lameness equals around 0.1 , which maximally reduces the attention of scientists to the genetic constituent of this problem. The assessment of laminitis inheritance, according to the results of the studies (Prakash et al., 2019) was even lower $(0.07 \pm 0.01)$. One study (Oikonomou et al., 2011) reports that for mastitis and laminitis, despite the low level of inheritance of these diseases, the selection based on genetic markers could be more important than the methods of typical selection. Swalve et al. (2014) revealed strong association of singular SNP on chromosome 21 with sensitivity to laminitis and assumes that genetic selection for improvement of resistance to laminitis is possible.

Currently, the molecular-genetic markers are essential in the sphere of animal genetics, because they allow determination of polymorphism at the level of DNA (DNA-markers). For cattle, there is a broad range of options of DNA-markers (Singh et al., 2014). During the selection of a marker needed for the identification of associations with different diseases of cattle, one should take into account its informativeness, the level of complexity of typing and cost of the work, therefore such studies should be conducted using a large number of animals.

From all the diversity of molecular-genetic markers, BoLA-DRB3 gene is unique. This is one of the genes of the Major Histocompatibility Complex (MHC). It is characterized by high level of polymorphism, associated with the formation of immune response of the organism to bacterial infections. Product of BoLA-DRB3 gene directly participates in binding of alien antigens and underlies the specificity of immune response. The second exon of BoLA-DRB3 gene which encodes II class $\beta_{1^{-}}$ domain is polymorphic due to the necessity of binding a broad range of alien antigens. The highest polymorphism of alleles of this gene indicates the possibility of high level of results from the search of possible markers associated with the diseases.

The significance of selection of BoLA-DRB3 gene as DNA-marker of sensitivity to various diseases of cattle is confirmed by the studies of its allele polymorphism in different breeds in many countries. The studies performed earlier allowed a large amount of data to be accumulated on the presence and the pattern of distribution of alleles and genotypes of BoLADRB3.2 gene for different populations, allowing performance of preliminary analysis regarding their use as DNA-markers for various diseases (Sulimova, 2006; Behl et al., 2012; Kumari et al., 2019). Variability of BoLA-DRB3 gene requires a broad scope of studies. A large number of studies focuses of biodiversity of cattle breeds (Takeshima et al., 2014; Takeshima et al., 2015; Peters et al., 2018) and search of its association with economic-practical features (Nascimento et al., 2006; Rupp et al., 2007). Today, a number of studies have been undertaken to identify the polymorphism of BoLA-DRB3 gene for Ukrainian breeds. On their basis, molecular-genetic markers have been found associated with mastitis for black-and-white and red-and-white breeds (Suprovych, 2013).

The objective of the study was identifying the DNA-markers (alleles of exon 2 of BoLA-DRB3 gene) for the Ukrainian black-and-white dairy breed susceptible (susceptibility or resistance) to nectobacteriosis.

\section{Materials and methods}

The Ukrainian black-and-white dairy breed was bred as a cross-breed of the black-and white domestic breed and the Holstein breed. In the breed, three intra-breed types were found, which differ by maternal base and part of inheritance from the Holstein breed. The maternal base of western and Polesia types, to which the populations belonged, have been formed by crossing of black-and-white, Ukrainian white-headed, Simmental breeds with Holstein bulls. The studies were conducted in the laboratory of the Genetics of the Institute of Animal Breeding and Genetics nd. a. M. V. Zubets of National Academy of Agrarian Science of Ukraine (Chubynske village of Kyiv Oblast) on the samples of blood from Ukrainian black-and-white dairy cows from two farms in Khemelnytsk Oblast: Perlyna Podillya Scientific-Production Agrofirm (herd 1, $\mathrm{n}=85$ ) and Ridnyy Kray branch (herd 2, n=91). Herd 1: loose housing, the floor on the farm was partly faced with plates and partly was wooden (in the place where the cows were held), the diet of cows was calculated for the groups depending on the animals' dairy productivity and com- prised the following feed: hay, silage, soy, sunflower, grain stillage, rape, salt, iodine). The diet was balanced and contained no additives, which is important for obtaining highest quality milk). The modern technologies of feeding were used, technological service and milking. Herd 2 were held in the following conditions: stanchion-tied housing in stables, in the typical farm in winter, in the summer camp from spring to autumn, straw litter, manure was removed using chain transporters, the diet was standard (wheat, peas, barley, extruded soy, premix, sunflower grist, silage, hay).

Nectobacteriosis was diagnosed according to the epizootological, clinical and pathonatomical data and the results of laboratory survey. In cases of purulent-necrotic lesion of the skin and the connective and muscular tissues adjacent to it, mainly on the lower parts of the limbs, we collected pathological material (the content of necrotic centers at the border of healthy and necrotized tissues) for isolation of Fusobacterium necrophorum.

Allele frequencies were determined according to the restriction analysis of polymorphism of exon 2 of the products of amplification of BoLADRB3 gene (Van Eijk et al., 1992; Gelhaus et al., 1995; Maillard et al., 1999). DNA from the blood samples was isolated using the standard commercial set DNK-sorb V manufactured by AmpliSens Company (Scientific-Research Institute of Epidemiology, Moscow, Russia) according to the modified protocol with application of the complex of reagents for isolation of DNA from liquid blood. The DNA isolated from pure biological material (output $-5-10 \mathrm{mg}$ from $200 \mathrm{~mL}$ of the whole blood) had high molecular mass (40-50 bp) and was a pure substance $\left(\mathrm{OD}_{260280 \mathrm{~nm}}=1.6-2.0\right)$. Concentration and frequency of DNA were measured using spectrophotometry and electrophoresis in $1 \%$ agarose gel (Agarose, Biotechnology grade, Helicon). For this purpose, DNA of phage $\lambda$ in the amount of 25,50 or $100 \mathrm{ng}$ and aliquots from solution with unknown concentration were applied to the gel. Electrophoresis was performed at constant power of $120 \mathrm{~W}$ in TBE buffer ( $89 \mathrm{mM}$ Tris-OH, $89 \mathrm{mM} \mathrm{H}_{3} \mathrm{BO}_{3}, 2 \mathrm{mM}$ EDTA) with addition of ethidium bromide $(1 \mu \mathrm{g} / \mathrm{mL})$ into the gel for staining of DNA. To avoid contamination, the electrophoresis was performed in a separate room. Concentration of DNA of the studied samples was determined by comparing the intensity of fluorescence of aliquots from the solutions with unknown concentration and the control titration of DNA of phage $\lambda$. They were analyzed under the ultraviolet rays on the UVT transilluminators, Biokom, and photographed using MINITRON system.

Exon 2 of BoLA-DRB3 gene was amplified using PCR (Van Eijk et al., 1992), conducted using ready-to-use sets manufactured by AmpliSens (Scientific-Research Institute of Epidemiology, Moscow, Russia). The total amount of the mixture $(20 \mu \mathrm{L})$ contained $60 \mathrm{mM}$ Tris-HCL (pH 8.8), $2.5 \mathrm{mM} \mathrm{MgCl}, 20 \mathrm{mM} \mathrm{KCl}, 15 \mathrm{mM}\left(\mathrm{NH}_{4}\right)_{2} \mathrm{SO}_{4}, 10 \mathrm{mM}$ mercaptoethanol, $0.1 \%$ Triton X-100, $0.2 \mathrm{mM}$ dNTP, $10 \mathrm{U}$ of Klentaq DNA polymerase, $10 \mathrm{pM}$ of each primer, matrix DNA. For the first round, we used oligonucleotide primers:

HLO-30 (5'-3': TCCTCTCTCTGCAGCACATTTCC), HLO-31 (5'-3': ATTCGCGCT CACCTCGCCGCT);

for the second round-

HLO-30 and HLO-32 (5'-3': TCGCCGCTGC ACAGTGAAACTCTC).

PCR-products of the first round $(2 \mu \mathrm{L})$ were used for the second round. PCR was conducted in the Tertsyk amplifier of DNA-Technology firm. The first period: denaturation of DNA at $95^{\circ} \mathrm{C}$ during $5 \mathrm{~min}$., then 10 cycles of denaturation $\left(94^{\circ} \mathrm{C}\right.$ during $1 \mathrm{~min}$.), hybridization of the primers $\left(62.5^{\circ} \mathrm{C}\right.$ during $2 \mathrm{~min}$.), DNA synthesis $\left(72^{\circ} \mathrm{C}\right.$ during $1 \mathrm{~min}$.) and the final synthesis $\left(72^{\circ} \mathrm{C}\right.$ during $7 \mathrm{~min}$.). The second period: the initial denaturation ( $95^{\circ} \mathrm{C}$ during $5 \mathrm{~min}$.), 35 cycles of denaturation, hybridization of the primers and synthesis of DNA $\left(94,68\right.$ and $72^{\circ} \mathrm{C}$ during $0.5 \mathrm{~min}$.) and final synthesis $\left(72^{\circ} \mathrm{C}\right.$ during $7 \mathrm{~min}$.). To avoid the contamination, the reaction mixture for all types of analyses was collected in a separate room using an individual set of pipettes. The final product of PCR in the amount of $5 \mu \mathrm{L}$ was subjected to electrophoresis on $1.8 \%$ agarose gel to test the quality and specificity of the DNA amplification fragments.

The products of PCR were treated with three restriction endonucleases: RsaI, HaeIII, Xholl (Promega, New England BioLabs and SibEnzim). Fragments of the restriction were divided using electrophoresis in $2 \%$ agarose gel and $9 \%$ polyacrylamide gel in TBE electrophoresis buffer (TBE: $0.089 \mathrm{M}$ of boric acid, 0.002 M EDTA pH 8.0). Electrophoresis of 
the agarose gel was performed in the horizontal chamber for 1-3 hours at the power of $2 \mathrm{~V} / \mathrm{cm}$ of gel. The gels were stained using ethidium bromide $(0.5 \mu \mathrm{L} / \mathrm{mL})$ for $10 \mathrm{~min}$. with their subsequent rinsing in distilled water. Fragments of DNA were visualized in UV light on the transilluminator at the wavelength of $280 \mathrm{~nm}$. To measure the length of the fragments, we used the marker of the molecular weights GeneRuler TM Ultra Low Range DNA Ladder manufactured by Fermentas, Latvia. As a result, analyzable electrophoregrams were developed (Fig. 1).
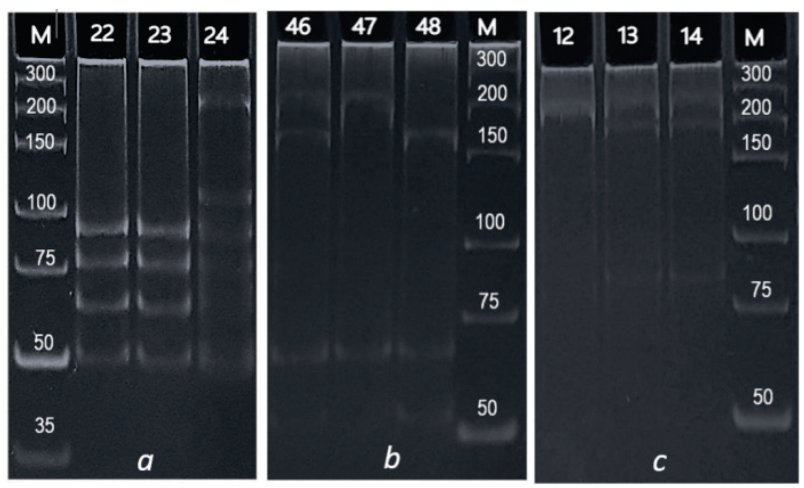

Fig. 1. Fragments of electrophoregrams of the products of the amplifycation of exon 2 of BoLA-DRB3 gene from DNA of cows of Ukrainian

black-and-white breed using endonucleases RsaI $(a)$, HaeIII $(b)$ and

HhoII (c): M - marker of the molecular weights GeneRuler ${ }^{\mathrm{TM}}$ Ultra Low

Range DNA Ladder; numbers of blood samples are indicated at the top

Amplification of exon 2 with the following analysis of the length of the restriction fragments and comparison of the DNA samples obtained using three values of the restriction endonucleases allows 54 alleles to be identified.

The frequencies of alleles were measured taking into account the number of homozygotes $\left(\mathrm{N}_{1 \mathrm{i}}\right)$ and heterozygotes $\left(\mathrm{N}_{2 \mathrm{i}}\right)$ found for the corresponding allele according to the formula ( $\mathrm{N}-$ amount of the selection):

$$
\mathrm{P}(\mathrm{A})=0.5\left(2 \mathrm{~N}_{\mathrm{li}}+\mathrm{N}_{2 \mathrm{i}}\right) / \mathrm{N} \text {. }
$$

The strengths of the associative connection are determined based on the relative risk (RR) which indicates by how many times the danger of the development of the disease is higher in the presence of a certain allele or genotype than in its absence. Allele indicates close relationship with the disease if the condition $\mathrm{RR} \geq 2 \mathrm{i} \chi^{2}>3.84(\mathrm{P}<0.05)$ is fulfilled. If the value $R R \leq 0.5$, than presence of allele in the genotype of animals indicates close association with the resistance (relative risk is recorded if $1 / \mathrm{RR}$ with minus sign).

Test $\chi^{2}$ makes sense if there are no less than 20 samples and the following conditions are created (a, c - animals susceptible to the disease, having or not the corresponding allele, $\mathrm{b}, \mathrm{d}$-animals resistant to the disease, having or not the corresponding alleles):

$$
\begin{aligned}
& (\mathrm{a}+\mathrm{b})(\mathrm{a}+\mathrm{c}) / \mathrm{N}>5,(\mathrm{a}+\mathrm{b})(\mathrm{b}+\mathrm{d}) / \mathrm{N}>5, \\
& (\mathrm{c}+\mathrm{d})(\mathrm{a}+\mathrm{c}) / \mathrm{N}>5,(\mathrm{c}+\mathrm{d})(\mathrm{b}+\mathrm{d}) / \mathrm{N}>5 .
\end{aligned}
$$

If there was observed a slight deviation according to $\chi^{2}$ or one of the conditions of the formula 2 was not fulfilled, then to determine the strength of the association, we performed a test using the Fisher exact test (p) and Pearson coefficient (C).

We hereby declare all ethical standards have been respected in preparation of the submitted article. Permission to use animals was approved by the State Agrarian and Engineering University in Podilya in accordance with the European Convention for the Protection of Vertebrate Animals used for Experimental and other Scientific Purposes.

\section{Results}

Our study revealed respectively 27 (herd 1) and 25 (herd 2) alleles (Table 1). Most often (average value for two selections) BoLA-DRB3.2*22 allele $(11.37 \%)$ was found. The first ten of the commonest alleles includes the same 9 variants in each one: $* 01, * 03, * 07, * 08, * 16, * 22, * 23, * 24$ and $* 28$. Their total frequency accounted for $71.3 \%$, in herd 1 , and $67.0 \%$ in herd 2. There were seen characteristic peculiarities of the distribution of alleles in the groups of infected and healthy cows. In the selections of susceptible animals in the both herds, 22 alleles in each were found, of which the commonest variant was the variant with BoLA-DRB3.2*16 $(16.1 \%)$. In the first ten of the commonest, the same 6 alleles in each were observed: $* 01, * 08, * 16, * 22, * 23$ and $* 24$, total frequency of which accounted respectively for $56.6 \%$ in herd 1 and $56.3 \%$ in herd 2 .

\section{Table 1}

Frequency (\%) of alleles of BoLA-DRB3.2 gene of Ukrainian

\begin{tabular}{|c|c|c|c|c|c|c|}
\hline \multirow[b]{2}{*}{ Alleles } & \multicolumn{2}{|c|}{ General selection } & \multicolumn{2}{|c|}{ infected } & \multicolumn{2}{|c|}{ healthy } \\
\hline & $\begin{array}{l}\text { herd } 1 \\
(n=85)\end{array}$ & $\begin{array}{l}\text { herd } 2 \\
(n=91)\end{array}$ & $\begin{array}{l}\text { herd } 1 \\
(n=38)\end{array}$ & $\begin{array}{c}\text { herd } 2 \\
(n=40)\end{array}$ & $\begin{array}{l}\text { herd } 1 \\
(n=47)\end{array}$ & $\begin{array}{c}\text { herd 2 } \\
(n=51)\end{array}$ \\
\hline$* 01$ & 4.71 & 9.34 & 2.63 & 5.00 & 6.38 & 12.80 \\
\hline$* 03$ & 7.06 & 7.14 & 2.63 & 2.50 & 10.60 & 10.80 \\
\hline$* 06$ & 1.76 & 2.20 & 1.32 & 3.75 & 2.13 & 0.98 \\
\hline$* 07$ & 4.71 & 3.30 & 1.32 & 2.50 & 7.45 & 3.92 \\
\hline$* 08$ & 11.20 & 4.95 & 9.21 & 7.50 & 12.80 & 2.94 \\
\hline *10 & 0.00 & 3.85 & 0.00 & 6.25 & 0.00 & 1.96 \\
\hline$* 11$ & 6.47 & 0.00 & 5.26 & 0.00 & 7.45 & 0.00 \\
\hline *12 & 2.35 & 1.65 & 2.63 & 0.00 & 2.13 & 2.94 \\
\hline *13 & 2.35 & 2.20 & 3.95 & 2.50 & 1.06 & 1.96 \\
\hline$* 14$ & 0.59 & 2.75 & 0.00 & 5.00 & 1.06 & 0.98 \\
\hline *16 & 9.41 & 8.24 & 15.80 & 16.30 & 4.26 & 1.96 \\
\hline *18 & 1.76 & 2.75 & 2.63 & 5.00 & 1.06 & 0.98 \\
\hline$* 21$ & 1.18 & 1.65 & 1.32 & 2.50 & 1.06 & 0.98 \\
\hline$* 22$ & 12.40 & 10.40 & 5.26 & 5.00 & 18.10 & 14.70 \\
\hline$* 23$ & 5.29 & 7.69 & 9.21 & 15.00 & 2.13 & 1.96 \\
\hline *24 & 8.24 & 9.34 & 14.50 & 7.50 & 3.19 & 10.80 \\
\hline *26 & 1.18 & 2.20 & 0.00 & 2.50 & 2.13 & 1.96 \\
\hline$* 28$ & 8.24 & 6.59 & 9.21 & 3.75 & 7.45 & 8.82 \\
\hline *32 & 1.18 & 1.10 & 0.00 & 0.00 & 2.13 & 1.96 \\
\hline *35 & 1.76 & 0.00 & 2.63 & 0.00 & 1.06 & 0.00 \\
\hline *36 & 1.18 & 2.75 & 1.32 & 1.25 & 1.06 & 3.92 \\
\hline$* 37$ & 0.59 & 2.75 & 1.32 & 1.25 & 0.00 & 3.92 \\
\hline *39 & 1.18 & 0.00 & 2.63 & 0.00 & 0.00 & 0.00 \\
\hline$* 45$ & 3.53 & 0.00 & 1.32 & 0.00 & 5.32 & 0.00 \\
\hline$* 51$ & 1.18 & 0.00 & 2.63 & 0.00 & 0.00 & 0.00 \\
\hline other & 14.10 & 11.50 & 9.21 & 7.50 & 6.38 & 24.50 \\
\hline $\begin{array}{l}\text { Alleles } \\
\text { in total }\end{array}$ & 25 & 27 & 22 & 22 & 21 & 27 \\
\hline
\end{tabular}
black-and-white cows in the general selection, among those suffering from nectobacteriosis and healthy animals

Note: other-alleles with the overall frequency of less than $2 \%$.

In the groups of the nectobacteriosis-resistant cows, there were found respectively 21 and 27 alleles, of which the commonest was BoLADRB3.2*22 allele (16.3\%). The first ten of the commonest alleles included the same 6 variants in each: $* 03, * 07, * 08, * 22, * 24$ and $* 28$. Their total frequency was $59.6 \%$ in the herd 1 , and $52.0 \%$ in the herd 2 .

The main goal of the study was determining the molecular-genetic markers based on the alleles of gene BoLA-DRB3.2 of the nectobacteriosis-susceptible animals. Tables 2 and 3 demonstrate the results of the biometric calculations for alleles which have statistically significant associations with the diseases or resistance to it and may be potentially the DNA-markers of susceptibility or resistance to nectobacteriosis.

Table 2

\begin{tabular}{|c|c|c|c|c|c|c|c|}
\hline \multirow[b]{2}{*}{ Alleles } & \multirow[b]{2}{*}{$P(A)$} & \multirow[b]{2}{*}{$R R$} & \multirow[b]{2}{*}{$\chi^{2}$} & \multicolumn{4}{|c|}{ Check for limited sample size } \\
\hline & & & & $\frac{(a+b)(a+c)}{N}$ & $\frac{(a+b)(b+d)}{N}$ & $\frac{(c+d)(a+c)}{N}$ & $\frac{(c+d)(b+d)}{N}$ \\
\hline$* 03$ & 0.071 & -4.87 & 4.44 & 5.36 & 5.51 & 32.6 & 40.4 \\
\hline *16 & 0.094 & 4.96 & 7.32 & 7.15 & 10.40 & 30.9 & 38.2 \\
\hline$*_{22}$ & 0.124 & -4.82 & 7.43 & 9.39 & 8.40 & 28.6 & 35.4 \\
\hline$* 24$ & 0.082 & 5.98 & 7.78 & 6.26 & 9.06 & 31.7 & 39.3 \\
\hline
\end{tabular}

Alleles of gene of Ukrainian black-and-white dairy cows susceptible to nectobacteriosis (herd 1)

In both selections, two alleles in each were found, indicating the statistical significance $\left(\chi^{2}>3.84\right)$ regarding susceptibility $(R R \geq 2)$ or resistance $(\mathrm{RR} \leq-2)$ of the cows to nectobacteriosis.

In the first herd, BoLA-DRB3.2*16 $(\mathrm{P}<0.01)$ and $* 24$ alleles $(\mathrm{P}<$ $0.01)$ indicate close relationship with the pathology. With the resistance to the diseases, BoLA-DRB3.2 $* 03(\mathrm{P}<0.05)$ and $* 22$ alleles $(\mathrm{P}<0.01)$ 
were related. In the second herd, the BoLA-DRB3. $2 * 03(\mathrm{P}<0.05)$ and $* 22$ alleles $(\mathrm{P}<0.05)$ manifested associative relationship with the resistance to nectobacteriosis, and allele BoLA-DRB3.2*16 and BoLADRB3.2*23 showed quite strong association $(\mathrm{P}<0.001)$ with the disease.

Table 3

Alleles of BoLA-DRB3.2 gene of cows of Ukrainian

black-and-white dairy breed susceptible to nectobacteriosis (herd 2)

\begin{tabular}{cccccccc}
\hline \multirow{2}{*}{ Alleles } & & \multirow{2}{*}{ R } & \multirow{2}{*}{$\chi^{2}$} & \multicolumn{5}{c}{ Check for limited sample size } \\
\cline { 5 - 8 } & & & $\frac{(a+b)(a+c)}{N}$ & $\frac{(a+b)(b+d)}{N}$ & $\frac{(c+d)(a+c)}{N}$ & $\frac{(c+d)(b+d)}{N}$ \\
\hline$* 03$ & 0.071 & -5.23 & 5.03 & 5.71 & 6.0 & 34.3 & 43.7 \\
$* 16$ & 0.082 & 11.80 & 13.30 & 6.59 & 10.2 & 33.4 & 42.6 \\
$* 22$ & 0.104 & -3.75 & 5.11 & 8.35 & 8.35 & 31.7 & 40.4 \\
$* 23$ & 0.077 & 10.50 & 11.70 & 6.15 & 9.38 & 33.9 & 43.2 \\
\hline
\end{tabular}

The analysis of the biometric parameters of others alleles showed at least two variants worth attention regarding the possibility of using them as molecular-genetic markers among the alleles found in this study (Table 4).

\section{Table 4}

Alleles of BoLA-DRB3.2 gene of Ukrainian

black-and-white dairy cows susceptible to nectobacteriosis which have limitations during detection of the associations

\begin{tabular}{lllllccc}
\hline \multirow{2}{*}{ Alleles } & $P(A)$ & $R R$ & \multirow{2}{*}{$\chi^{2}$} & \multicolumn{4}{c}{ Check for limited sample size } \\
\cline { 4 - 7 } & & $\frac{(a+b)(a+c)}{N}$ & $\frac{(a+b)(b+d)}{N}$ & $\frac{(c+d)(a+c)}{N}$ & $\frac{(c+d)(b+d)}{N}$ \\
\hline $\begin{array}{c}* 23 \\
\text { (herd 1) }\end{array}$ & 0.053 & 5.08 & 4.45 & $4.02^{* *}$ & 5.51 & 34.0 & 42.0 \\
$\begin{array}{c}* 01 \\
\text { (herd2) }\end{array}$ & 0.093 & -3.08 & $3.54^{* *}$ & 7.47 & 7.85 & 32.5 & 41.5 \\
\hline
\end{tabular}

Note: ** - parameters the value of which excess the acceptable thresholds.

BoLA-DRB3. $2 * 01$ allele is limited from the perspective of the biological studies $\left(\chi^{2}<3.84 ; \mathrm{P}=0.06\right)$, and BoLA-DRB3.2*23 allele did not stand up to the test for the size of selection due to low number of the animals with the variants $a=7$ and $b=2$.

For the evaluation of the statistical significance of the strength of the association of the sensitivity to nectobacteriosis, Fisher's exact test was performed with testing the strength of the association according to the Pearson coefficient. For allele $* 23$, we determined that $\mathrm{p}=0.031$ and $\mathrm{C}=$ 0.223 , and for allele $* 01-\mathrm{P}=0.038$ and $\mathrm{C}=0.194$. Both variants have stood the test with the exact criterion $(\mathrm{P}<0.05)$, allowing us to propose them for the practical use as DNA-markers. However, mean and weak strength of the association according to the Pearson coefficient suggests that the approach in interpreting such opportunity must be cautious. For the final decision on the possibility of using these alleles as DNA-markers associated with nectobacteriosis, additional studies should be undertaken.

\section{Discussion}

The high level of polymorphism and heterozygosity of BoLA-DRB3 gene helps the immune system to react to a broad range of pathogens. The uniqueness of this area of DNA has concentrated the attention of scientists. Over the recent 20 years, using PCR-RFLP and PCR-SBT, allele spectrum of over 30 breeds of cattle around the globe has been identified (Ranjbar et al., 2017). Currently, 330 DRB3-alleles have been recorded in the Immuno Polymorphism Database (IPD)-MHC database (www.ebi.ac.uk/ipd/mhc/group/BoLA). Most studies focused on the identification of associations of BoLA-DRB3.2 alleles and the following diseases: mastitis (Kulberg et al., 2007), leucosis (Gutiérrez et al., 2017), hoof-and-mouth disease (Lei et al., 2012), diseases caused by Acari (Duangjinda et al., 2013), rejection of the placenta, dermatophiliosis, pancytopenia (Ibeagha-Awemu et al., 2008; Behl et al., 2012) etc.

The Ukrainian black-and-white breed is diverse in genealogical structure, which is confirmed by the results of typing of blood samples of both herds. Polymorphism of alleles of BoLA-DRB3.2 gene ranges within a broad spectrum, both according to the quantity and the nomenclature. In our study, in the herd 1, 27 variants were found, while in the herd 2 -
25. This is an average indicator. A maximum of 35 alleles of a possible 54 PCR-RFLP variants were identified for Mongolian cattle (Ruzina et al., 2010). Greater diversity was characteristic of only the Filipino cattle, in which 71 alleles were detected using PCR-SBT method (Takeshima et al., 2014). According to the review (Behl et al., 2012), the lowest polymorphism was determined for Jersey and Rathi breeds, 13 alleles of BoLADRB3.2 gene for each. It should be noted that the general frequency of the commonest alleles in cows of the Ukrainian black-and-white breed was lower than in other industrial breeds. The high level of consolidation of alleles indicates impoverishment of the genetic diversity of the breed. The pressure from breeders leads to allele funds of different breeds becoming more similar and genetically homogenous with time. In our study, the total frequency of such alleles was within $50-60 \%$, whereas the accumulation of alleles most often detected in American Holstein cattle accounted for $79.6 \%$ (Dietz et al., 1997), and $91.3 \%$ in Canadian cattle (Sharif et al., 1998).

The data of the study on the associations of MHC genes with the limb disorders of ruminants are quite limited. Genetic advantage is determined by the heredity of a feature, intensity of the selection, reliability of the selective values and the interval of the generation. Even if the heredity is low, genetic differences exist (Van der Linde et al., 2010). This is indicated by the results of the studies we published earlier (Suprovich et al., 2016) regarding the associations of alleles of BoLA-DRB3.2 gene with the nectobacteriosis of Ukrainian black-and-white breed on the basis of the breeding herd Kozatska Dolyna 2006, performed using the methods and on the basis of the Laboratory of Genetics of the Vavilov Institute of General Genetics (Moscow). The allele polymorphism was studied on the blood samples from 114 cows (43 animals diagnosed nectobacteriosis). Total of 4 alleles were determined to have susceptibility to the disease: * 16 $(\mathrm{RR}=24.10 ; \mathrm{P}<0.001),{ }^{*} 23(\mathrm{RR}=4.41 ; \mathrm{P}<0.05),{ }^{*} 03(\mathrm{RR}=-7.70 ; \mathrm{P}<$ $0.05)$ and $* 22(\mathrm{RR}=-3.57 ; \mathrm{P}<0.05)$. It has to be noted (Suprovych, 2013) that BoLA-DRB3.2*22 allele which manifested itself as a marker of resistance to nectobacteriosis has also a close relationship with the resistance to mastitis in cows of Ukrainian black-and-white $(R R=-2.52$; $\mathrm{P}<0.05)$ and red-and-white dairy breeds $(\mathrm{RR}=-4,66 ; \mathrm{P}<0.001)$. The relationship between mastitis and lameness of cows is reported in the study undertaken in 10 dairy farms in South-West England (Peeler et al., 1994). The assessment of the relationships between the periphery diseases of 3,603 cows over three lactations using logistic regression revealed that the clinical lameness is related to 1.4 times increase in the chances of clinical mastitis.

Currently, among other studies, only one work is known which was oriented towards the identification of associations of BoLA-DRB3 gene with laminites in a dairy breed, performed by Chinese scientists (Sun et al., 2013). They studied the relationship between polymorphism of gene and lameness of Chinese Holstein cows $(n=435)$ and came to the conclusion that RLFP alleles of exon 2 may be candidates of susceptibility to limb diseases in that population. The study was based on identifying genotypes of cows using the restrictases BstUI, BstYI and HaeIII (MBI fermentas, China). Analysis of seven RFLP genotypes with HaeIII restrictase showed presence of statistically significant associations with laminitis in the Chinese cattle.

Among the reports on search of genetic markers in relation to lameness of cattle, we should draw attention to the studies (Buitenhuis et al., 2007) where the genome was scanned for QTL on the basis of 29 autosomes using microsatellite markers and (Oikonomou et al., 2011) who studied the influence of polymorphism of loci of STAT5A and FGF2 genes on the diseases of limbs of Holstein cows. The study (Ferchichi et al., 2018a) presents the results of research of the genetic polymorphism of FGF-2 gene and its influence on the lameness of Holstein cows in Tunisia. In another work (Ferchichi et al., 2018b), the influence of polymorphism of leptin gene on the lameness of cows $(n=412)$ was studied. The researches revealed that the animals with $\mathrm{AB}$ genotype have less lameness than cows with homozygote genotypes $\mathrm{BB}$ and $\mathrm{AA}$.

Genome-wide association study showed significant amount of SNP associated with different disorders of hooves. In general, 11 significant and 46 suggestive SNP-associations related to the pathology of hooves on 20 chromosomes were found (Van der Spek et al., 2015). Also, there is a report about the search of similar associations in sheep. The animals were 
selected into the groups of correspondence to the inherited paternal haplotype (Escayg et al., 1997) for studying the relationships between MHC locus of class II and the status of footrot. The study revealed the associations of MHC haplotype and the status of the disease $(\mathrm{P}=0.005)$. Another research work (Valilou et al., 2016) provides the data of studying the polymorphisms of Ovar-DRB1 and BMC5221 genes for the identification of animals resistant to lameness (footrot) among Ghezel sheep. Statistical analysis of Ovar-DRB1 alleles demonstrated high frequencies of FF and $\mathrm{AA}$ genotypes in animals resistant to lameness $(\mathrm{P}<0.01)$, whereas more common frequencies of DD genotype were seen in susceptible animals $(\mathrm{P}<0.01)$. In BMC5221 locus, higher frequencies of A1A3 genotype were observed in the animals resistant to lameness $(\mathrm{P}<0.01)$, while higher frequencies of $\mathrm{A} 3 \mathrm{~A} 3$ and $\mathrm{A} 2 \mathrm{~A} 2$ genotypes were observed in susceptible animals $(\mathrm{P}<0.01)$.

The future of selective breeding of cattle cannot be based only on the short-term purposes oriented towards the profitability of the production of animal origin. Traditionally, the programs of livestock farming had a special focus on the genetic improvement of economically important characteristics: milk, fat and protein. Genetic progress has been quite successful regarding these indicators. After introduction of complex models of genetic assessment and improvement of genetic selection, milk production increased more than twice over the last 40 years. But as the genetic ability of cows to produce milk heightened, their health and welfare were significantly damaged. Today, dairy cows suffer from serious problems such as mastitis, lameness and infertility. Also, the productive period of use of these animals decreased. This means that currently, maintaining the level of usefulness requires higher standards of management and costs.

The fact that the actual (phenotypical) relationships between health and production, usually, are much lower than the genetic ones indicates that this problem is being successfully solved. However, if genetics behind health- and life span-related problems is ignored, the welfare of herds will decrease below the acceptable level. Therefore, the genetic data on the peculiarities of health and welfare of animals is becoming more and more valuable. Moreover, the genetic improvements are very economical, constant and accumulate over generations. Finally, the accurately implemented genome technologies using DNA-markers, including the ones based on alleles of BoLA-DRB3.2 gene, could give new solutions of this increasingly complex problem of animal selective breeding, where we often face controversial genetic wishes of maximum output of animal production compared with resistance to diseases.

\section{Conclusions}

We found associations of alleles of exon 2 of BoLA-DRB3 gene with nectobacteriosis in cattle. BoLA-DRB3. $2 * 03$ and $* 22$ alleles associated with resistance, while $* 16$ and $* 23$ are associated with susceptibility to nectobacteriosis of cows in both studied herds. Furthermore, the first herd was found to have one more allele $* 24$, which indicates strong relationship with the disease. Similar results were obtained in earlier studies on the Ukrainian black-and-white dairy breed, confirming the genetic relation between BoLA-DRB3 gene and nectobacteriosis.

It is determined that molecular-genetic markers are potentially useful, because they allow controlling possible manifestations of nectobacteriosis, which is the main cause of lameness of dairy cows, at the early stages of ontogenesis. Genetic selection for resistance to nectobacteriosis and health improvement of dairy herds against lameness could be based on the found BoLA-DRB3 alleles.

The results of the study once again confirm the importance of MHC in the animal husbandry and significantly extend our knowledge of diversity and polymorphism in this locus.

To obtain knowledge about the role of gene in the mechanism of immune protection against limb diseases caused by nectobacteriosis, other breeds of cattle need to be additionally studied.

\section{References}

Behl, J. D., Verma, N. K., Tyagi, N., Mishra, P., Behl, R., \& Joshi, B. K. (2012). The major histocompatibility complex in bovines: A review. ISRN Veterinary Science, 2012, 872710.

Boettcher, P. J., Dekkers, J. C., \& Warnick, L. D., Wells, S. J. (1998). Genetic analysis of clinical lameness in dairy cattle. Journal of Dairy Science, 81(4), 1148-1156.

Buitenhuis, A. J., Lund, M. S., Thomasen, J. R., Thomsen, B., Nielsen, V. H., Bendixen, C., \& Guldbrandtsen, B. (2007). Detection of quantitative trait loci affecting lameness and leg conformation traits in Danish Holstein cattle. Journal of Dairy Science, 90(1), 472-481.

Cha, E., Hertl, J. A., Bar, D., \& Gröhn, Y. T. (2010). The cost of different types of lameness in dairy cows calculated by dynamic programming. Preventive Veterinary Medicine, 97, 1-8.

Dietz, A. B., Cohen, N. D., Timms, L., \& Kehrli, M. E. (1997). Bovine lymphocyte antigen class II alleles as risk factors for high somatic cell counts in milk of lactating dairy cows. Journal of Dairy Science, 80(2), 406-412

Duangjinda, M., Jindatajak, Y., Tipvong, W., Sriwarothai, J., Pattarajinda, V., Katawatin, S., \& Boonkum, W. (2013). Association of BoLA-DRB3 alleles with tick-borne disease tolerance in dairy cattle in a tropical environment. Veterinary Parasitology, 196(3-4), 314-320.

Escayg, A. P., Hickford, J. G., \& Bullock, D. W. (1997). Association between alleles of the ovine major histocompatibility complex and resistance to footrot. Research in Veterinary Science, 63(3), 283-287.

Ettema, J. F., \& Østergaard, S. (2006). Economic decision making on prevention and control of clinical lameness in Danish dairy herds. Livestock Science, 102, 92-106.

Ferchichi, M. A., Jemmali, B., Amiri, S., Bejaoui, S., Ben Gara, A., \& Rekik, B. (2018a). Association of lameness incidence and FGf-2 polymorphism. Journal of New Sciences, Sustainable Livestock Management, 9(4), 196-201.

Ferchichi, M. A., Jemmali, B., Amiri, S., Ben Gara, A., \& Rekik, B. (2018b). Effect of leptin genetic polymorphism on lameness prevalence in Tunisian Holstein cows. Archives Animal Breeding, 61, 305-310.

Gelhaus, A., Schnittger, L., Mehlitz, D., Horstmann, R. D., \& Meyer, C. G. (1995). Sequence and PCR-RFLP analysis of 14 novel BoLA-DRB3 alleles. Animal Genetics, 26(3), 147-153.

Gutiérrez, S. E., Esteban, E. N., Lützelschwab, C. M., \& Juliarena, M. A. (2017). Major histocompatibility complex-associated resistance to infectious diseases: The case of bovine leukemia virus infection. Trends and Advances in Veterinary Genetics, $2017,65804$.

Hedges, J., Blowey, R. W., Packington, A. J., O’Callaghan, C. J., \& Green, L. E. (2001). A longitudinal field trial of the effect of biotin on lameness in dairy cows. Journal of Dairy Science, 84(9), 1969-1975.

Heringstad, B., Egger-Danner, C., Charfeddine, N., Pryce, J. E., Stock, K. F., Kofler, J., Sogstad, A. M., Holzhauer, M., Fiedler, A., Müller, K., Nielsen, P., Thomas, G., Gengler, N., de Jong, G., Ødegård, C., Malchiodi, F., Miglior, F., Alsaaod, M., \& Cole J. B. (2018). Invited review: Genetics and claw health: Opportunities to enhance claw health by genetic selection. Journal of Dairy Science, 101, 1-21.

Ibeagha-Awemu, E. M., Kgwatalala, P., Ibeagha, A. E., \& Zhao, X. (2008). A critical analysis of disease-associated DNA polymorphisms in the genes of cattle, goat, sheep, and pig. Mammalian Genome, 19(4), 226-245.

Kulberg, S., Heringstad, B., Guttersrud, O. A., \& Olsaker, I. (2007). Study on the association of BoLA-DRB3.2 alleles with clinical mastitis in Norwegian Red cows. Journal of Animal Breeding and Genetics, 124(4), 201-217.

Kumari, N., Loat, S., Saini, S., Dhilor, N., Kumar, A., \& Kataria, R. S. (2019). Role of BoLA-DRB3 genetic diversity against resistance to mastitis in cattle: Review. Journal of Veterinary Science and Research, 1, 30-36.

Lei, W., Liang, Q., Jing, L., Wang, C., Wu, X., \& He, H. (2012). BoLA-DRB3 gene polymorphism and FMD resistance or susceptibility in Wanbei cattle. Molecular Biology Reports, 39(9), 9203-9209.

Maillard, J. C., Renard, C., Chardon, P., Chantal, I., \& Bensaid, A. (1999). Characterization of 18 new BoLA-DRB3 alleles. Animal Genetics, 30, 200-203.

Nascimento, C. S., Machado, M. A., Martinez, M. L., Silva, M., Guimarães, M., Campos, A., Azevedo, A., Teodoro, R., Verneque, R., Guimarães, S., \& Oliveira, D. (2006). Association of the bovine major histocompatibility complex (BoLA) BoLA-DRB3 gene with fat and protein production and somatic cell score in Brazilian Gyr dairy cattle (Bos indicus). Genetics and Molecular Biology, 29(4), 641-647.

Oikonomou, G., Michailidis, G., Kougioumtzis, A., Avdi, M., \& Banos, G. (2011). Effect of polymorphisms at the STAT5A and FGF2 gene loci on reproduction, milk yield and lameness of Holstein cows. Research in Veterinary Science, 91(2), 235-239.

Ózsvári, L. (2017). Economic cost of lameness in dairy cattle herds. Journal of Dairy, Veterinary and Animal Research, 6(2), 00176.

Peeler, E. J., Otte, M. J., \& Esslemont, R. J. (1994). Inter-relationships of periparturient diseases in dairy cows. Veterinary Record, 34(6), 129-132. 
Peters, S. O., Hussain, T., Adenaike, A. S., Adeleke, M. A., De Donato, M., Hazzard, J., Babar, M. E., \& Imumorin, I. G. (2018). Genetic diversity of bovine major histocompatibility complex class II DRB3 locus in cattle breeds from Asia compared to those from Africa and America. Journal of Genomics, 12(6), 88-97.

Prakash, C., Gaur, G. K., Pruthviraj, D. R., \& Sahoo, N. R. (2019). Distribution analysis of single nucleotide polymorphisms related to feet and legs and their association with lameness in Vrindavani cattle. Tropical Animal Health and Production, 52, 851-858.

Ranjbar, M. M., Ataei, S., Nikbakht, G., \& Golabdar, S. (2017). Analysis of variations, structures, and phylogenic characteristics of bovine leukocyte antigen DRB3 exon 2. Archives of Razi Institute, 72(3), 147-157.

Rupp, R., Hernandez, A., \& Mallard, B. (2007). Association of bovine leukocyte antigen (BoLA) DRB3.2 with immune response, mastitis, and production and type traits in Canadian Holsteins. Journal Dairy Science, 90(2), 1029-1038.

Ruzina, M. N., Shtyfurko, T. A., Mohammad Abadi, M. R., Gendzhieva, O. B., Cedev, C., \& Sulimova, G. E. (2010). Polimorfizm gena BoLA-DRB3 u krupnogo rogatogo skota mongol'skoj, kalmyckoj i jakutskoj porod [Polymorphism of the BoLA-DRB3 gene in the Mongolian, Kalmyk, and Yakut cattle breeds]. Russian Journal of Genetics, 46(4), 517-525 (in Russian).

Sharif, S., Mallard, B. A., Wilkie, B. N., Sargeant, J. M., Scott, H. M., Dekkers, J. C., \& Leslie, K. E. (1998). Associations of the bovine major histocompatibility complex DRB3 (BoLA-DRB3) alleles with occurrence of disease and milk somatic cell score in Canadian dairy cattle. Animal Genetics, 29, 185-193.

Singh, U., Deb, R., Alyethodi, R., Alex, R., Kumar, S., Chakraborty, S., Dhama, K., \& Sharma, A. (2014). Molecular markers and their applications in cattle genetic research: A review. Biomarkers and Genomic Medicine, 6, 49-58.

Skorodumov, D. I. (2007). Mikrobiologicheskaja diagnostika nekrobakterioza [Microbiological diagnosis of necrobacillosis]. Veterinarija Sel'skohozjajstvennyh Zhivotnyh, 12, 21-25 (in Russian)

Sokolovsky, N. V., \& Birukova, O. D. (2016). The influence of genotypical and paratypical factors on the incidence of limb in cows of Ukrainian black-andwhite dairy breed. Animal Breeding and Genetics, 52, 114-119.

Sulimova, G. E. (2006). DNA markers in the study of gene pool of cattle breeds. Gene pools of farm animals: genetic resources of animal husbandry in Russia. Nauka, Moscow.

Sun, L., Song, Y., Riaz, H., Yang, L. (2013). Effect of BoLA-DRB3 exon 2 polymorphisms on lameness of Chinese Holstein cows. Molecular Biology Reports, 40(2), 1081-1086.

Suprovich, T., Karchevska, T., Kolinchuk, R., \& Mizyk, V. (2016). Vyiavlennia aleliv gena BoLA-DRB3.2, asocijovanih z nekrobakteriozom u koriv Ukrayinskoyi chorno-ryaboyi molochnoji porody [Determination of alleles of BoLA-DRB3.2 gene associated with necrobacteriosis of the cows of Ukrainian black-and-white dairy cattle]. Animal Breeding and Genetics, 51, 205-213 (in Ukrainian).

Suprovych, T. (2013). Doslidzhennja polimorfizmu gena BoLA-DRB3 u koriv spryjnjatlyvyh ta stijkyh do mastytiv [Study of gene polymorphisms BoLA-
DRB3 cows susceptible and resistant to mastitis]. Tvarynnyctvo Ukrainy, 12, 14-19 (in Ukrainian).

Suprovych, T. M., Suprovych, M. P., \& Kolinchuk, R. V. (2017). Naslidki “"golshtinizaciyi”" Ukrayinskoyi chorno-ryaboyi molochnoyi porodi za genom BoLA-DRB3.2 [Consequences of "holsteinization" of Ukrainian black-pied dairy breed by gene BoLA-DRB3.2]. Animal Breeding and Genetics, 54, 146-156 (in Ukrainian).

Swalve, H., Floren, C., Wensch-Dorendorf, M., Schöpke, K., Pijl, R., Wimmers, K., \& Brenig, B. (2014). A study based on records taken at time of hoof trimming reveals a strong association between the IQ motif-containing GTPase-activiating protein 1 (IQGAP1) gene and sole hemorrhage in Holstein cattle. Journal of Dairy Science, 97 (1), 507-519.

Takeshima, S. N., Miyasaka, T., Matsumoto, Y., Xue, G., Diaz, V., RogbergMunoz, A., Giovambattista, G., Ortiz, M., Oltra, J., Kanemaki, M., Onuma, M., \& Aida, Y. (2015). Assessment of biodiversity in Chilean cattle using the distribution of major histocompatibility complex class II BoLA-DRB3 allele. Tissue Antigens, 85(1), 35-44.

Takeshima, S. N., Miyasaka, T., Polata, M., Kikuya, M., Matsumoto, Y., Mingala, C. N., Villanueva, M. A., Salces, A. J., Onuma, M., \& Aida, Y. (2014). The great diversity of major histocompatibility complex class II genes in Philippine native cattle. Meta Gene, 2, 176-190.

Valilou, R. H., Sarskanroud, M. R., Rafat, S. A., Ebrahimi, M., Firouzamandi, M., \& Mohammadi, S. A. (2016). Association between footrot resistance and microsatellite polymorphisms of ovar-DRB1 and BMC5221 loci in Iranian Ghezel sheep. Revue de Medecine Veterinaire, 167(11-12), 316-322.

Van der Linde, C., De Jong, G., Koenen, E. P. C., \& Eding, H. (2010). Claw health index for Dutch dairy cattle based on claw trimming and conformation data. Journal of Dairy Science, 93, 4883-4891.

Van der Spek, D., Van Arendonk, J. A. M., \& Bovenhuis, H. (2015). Genomewide association study for claw disorders and trimming status in dairy cattle. Journal of Dairy Science, 98(2), 1286-1295.

Van Eijk, M. J. T., Stewart-Haynes, J. A., \& Lewin, H. A. (1992). Extensive polymorphism of the BoLA-DRB3 gene distinguished by PCR-RFLP. Animal Genetics, 23(6), 483-496.

Vinnikov, M. G., Melnik, R., Melnik, N. V., Samuylenko, A. Y., Grin, S. A. Klyukina, V., Svyatenko, M. S., Yartsev, S. D., \& Khaustova, N. V. (2019). Nekrobakterioz i meroprijatija po ego preduprezhdeniju u vysokoproduktivnogo importnogo skota [Necrobacteriosis and measures to prevent it in highly productive imported livestock]. Veterinaria i Kormlenie, 3, 32-35 (in Russian).

Zhovnir, O. M., Gorbatiuk, O. I., Andriyashchuk, V. A., Ryzhenko, G. F., Tiutiun, S. M., Rudoi, A. V., \& Kamenchuk, P. P. (2015). Monitoryng nekrobakteriozu, osnovnyj vydovyj spektr mikrobnyh asociacij za uchasti $F$. necrophorum ta specyfichni zasoby profilaktyky [Monitoring of necrobacillosis and species range of the most common microbial associations involving $F$. necrophorum]. Veterynarna Biotehnologija, 27, 112-121 (in Ukrainian). 